\title{
Internationalization of Universities: Trends for Adoption of Environmental Management System EMS-ISO 14001:2004 across Higher Education Sector Universities in Pakistan
}

\author{
Shahid Iqbal*, Maria Khan \\ Quality Enhancement Cell (QEC), COMSATS Institute of Information Technology (CIIT), Pakistan
}

Copyright (C) 2015 by authors, all rights reserved. Authors agree that this article remain permanently open access under the terms of the Creative Commons Attribution License 4.0 International License

\begin{abstract}
This study emphasized the results carried out on a sample of twenty Higher Education Commission (HEC) accredited universities in Pakistan, the prime purpose of which was to surface major constituents for the need of environmental standards in universities. EMS ISO 14001:2004 processes in overt and covert dynamics for their internationalization and the result being the less awareness level amongst various stakeholders about such processes and their resulting benefits. It aims in general, to decipher the viability and advantages of shifting to an environmental system ,the standards maintained by universities in relation to environment safety, and in particular the case study of a Pakistani , leading degree awarding university ,that showed interest in internalization by adopting EMS System. As a general process these standardizations are still in an early developing stage. The study thus indicates that minimal time duration of 8 to 20 months in order to acquire EMS certifications, and document controls. A case study in this research is of CIIT Pakistan and its struggle for obtaining international standardization including EMS. The methodology implied consisted of visits to relevant websites, questionnaires' and surveys conducted across 60 Pakistani leading universities. The study thus, resonates on two distinct levels of analysis: the benefits of adopting EMS by universities in general and the limitations of adopting EMS by Pakistani universities in particular, leading to performance changes resulting from implementation of such international standards and making their existence in international knowledge economic market of the world.
\end{abstract}

Keywords Internationalization of Pakistani Universities, Trends and Adoption of ISO Standards, Environmental Management System Development, Environmentally Green Future Campuses

\section{Introduction}

In higher education institutions of the world, relevant systems are being improved to cater the needs for improvements of practices which in turn are usually reflections of imprints of effective users' friendly management systems. These trends are now being adopted by Pakistani Universities. For the performance to be at the optimal level and for becoming leading star in international ranking all International standardization ISO systems should be well integrated. During the rudimentary stages, stress is laid only to document the overall management system, and at later stages, the operational implementation is catered. Implementation of EMS ISO 14001 in Pakistani higher education systems shall be maximized in the coming decade and continual improvements in universities of Pakistan, specifically in terms of products (student), services (Teaching \& research), people (faculty \& administration), and environment (campus ecology) for managing changes in their existing management systems. These systems encompass various steps associated with safety, protection and quality of campuses from potential hazards. They eliminate uncontrolled systems and weak managements. As per Voorhees \& Woellner [1] the ISO 14001:2004 EMS adoption in any international university shall require the strong motivation from the collective top management of university to staff.

Environmental management system (EMS) in higher education sector universities enables the universities to better engineer its programs related to environment and to document each one of them. It includes all the policy requirements (planning, organizing and structuring) for such endeavors. These conditions when finally met, lead to ISO 14001:2004 certification, Von Zharen [2]. ISO 14001:2004 EMS is such a standard that monitors the organizational activities related to environment in terms of its final 
outcomes. Any leading research university has an excess of areas such as staff, students and a huge space, a medical center. The adoption of such EMS standards leave significant impact on local, national and global environment and to conserve energy, provides clean healthy water, saves exchequer, make finite resources last longer and helps reduce pollution and contributes to climate change. Clements and Kuhre [3] were of the view that implementation of EMS processes also provides various services including legislation, pollution control, construction management which would be helpful in the enhancement of overall process. Block [4] finds a similarity between ISO 9001 and 14001. The need for both the systems has similar requirements, Hartstern [5]. Both the systems cannot operate without the commitment of top management, Block, 2000; Jackson, [6]

Generally, the demand of every organization is different in accordance with its specified needs, therefore, ISO 9001 caters quality and ISO 14001 caters environment aspects. Integration of the EMS and the QMS together, can result in a substantial cost saving, McDonald et al [7]. The common requirements for at least eight specific core areas in universities are: document Control, maintaining records, responsibility \& authority, management reviews on regular basis twice a year, training \& capacity development, introducing internal audit mechanisms, implementation of corrective measures and provision of infrastructure and conducive environment. Hoyle [8] highlighted some differences that exist between the ISO 9001 \& 14001 standards. Hartstern, [5] precipitated the non-conformities existing between standards and emphasized that the integrated strategy of a university could adopt these measures being a challenge. As per Annual Report of CIIT [9] the CIIT Pakistan was certified for ISO 9001:2008 in the year 2011 and afterwards regular internal and external surveillances were carried out with relevant training programs. The latest update on web portal of CIIT also indicates that the ISO 9001:2008 of all campuses has also been renewed through National Quality Assurance (NQA) under authorization of UKAS Management System UK, up to January 2018. This is indeed a positive sign for CIIT Pakistan that it is moving fast towards internationalization and achieving better position in international ranking. As for now the CIIT leadership intends to adopt EMS 14001:2004 in the years ahead. The lab systems shall also be upgraded through ISO 17025 certifications in future. The other Pakistani universities are also inspired for adoption of EMS and shall compete in the race of Internationalization in the upcoming decade.

\section{Discussion and Analysis}

This research was conducted by a team of two members of CIIT (COMSATS, Institute of Information Technology, Islamabad), Pakistan to measure the effectiveness and benefits of adopting ISO 14001 system in CIIT. The EMS ISO 14001:2004 introduction in the higher education sector in the world leading universities is becoming popular and its implementation in these particular areas of university education is very effective for attracting more and more international students, research and development projects funding and joint research programs in the race of making their presence in the competitive market of knowledge economy. In Pakistan about 10 universities in the higher education sector intended for competing international universities and inspired to adopt EMS and placing themselves in the queue of internationalization and achieving better position in national and international ranking. CIIT and other leading Pakistani universities are also trying for certification against this very important standard. To achieve this end of measuring the effectiveness of ISO systems, the international role model of South Carolina, university USA could be useful for adoption of EMS in Pakistani universities. This university has a well-managed ISO system. It also has occupational safety management systems along with hazardous waste pickup management systems, safety sheets, posters, emergency response systems. Any university that intends to adopt ISO 14001 opens doors for its own organizational performance in terms of environment. The university can reach to international market, a well-toned relationship with the Government, a good public and self-image and a reduction in overall environmental liabilities.

In the United States, over decades an improved attitude towards ISO 14001 was emerged that varied from mistrust to motivation and so is the case and trend emerging in Pakistani universities, a good example being LUMS (Lahore University of Management Sciences) and CIIT (COMSATS, Institute of Information Technology, Islamabad).These universities have made their own ISO 14001 road-maps. They do researches on GAP Analysis in order to access and determine elements that need more attention in strict compliance with the international standards.

The relevant areas were further analyzed by extensively using multiple materials and available resources such as Internet ,auditors interviews, university websites ,print (such as articles, journals ,books, annual reports )and electronic media (Internet databases )and not the least, conversations and meetings with all the stake holders. The universities adopting these systems were shown to have an increased employee retention and satisfaction rate in terms of IPE (Institutional performance evaluation) .The employees had the view that environment, ambiance and services need to be clean healthy and swift. The financial benefits a university attained were in terms of internationalization, attracting more students with a positive market image both at national and international arena.

The significant areas encountered during the research were included and indicated in the following Table-1; 
- Impacts related to environment - how can we look up for environmental impacts and the amount of benefits that one can ascertain?

- Performance related to environment- what can we do to measure environmental performance

Can we measure the effectiveness of performance indicators?

What effect does it have on environment?

- What is the motivation - what motivates a university to go forward with ISO 14001

How does this helps in employee retention?

- Cost /benefit of Adopting EMS - What benefits in terms of financial fronts do universities gain by adopting ISO 14001

- Audits - Is the EMS Audit a perceived impediment and limitation to certification?

\section{Historical Perspectives}

ISO center is in Geneva was formulated in the year as early in 1946 with the basic objectives of improvements in international coordination on standardizations. From February 1947, it started officiating categorically. The ISO abbreviation was originated from a word of Greek origin meaning "equal", the prime reason for the selection of a shorter version was because different countries would have varied slangs. It constitutes of 163 national bodies, each of which represents a country with the basic function of engineering and auditing standards worldwide to streamline the linkages easy and successful for future. The early 1970s was the year of the beginning of introducing the environmental systems, as 1970s faced many environmental disasters, the world started reacting, so in turn the EMS were formed, Schaarsmith [10]. The ones who make policies and the ones who are in academics pay less significance to manage solid wastes, Salim, [11]. There must be an appropriate way to control these processes so it is not harmful to our future generations. In the year 2004, USA was left behind by china, as china surpassed as the biggest generator of waste (The World Bank Report, 2005). "Reduction of waste and the management of campus and industry pollutant would emerge as the greatest confrontation of Singapore, Bai and Sutanto [12]. Malaysia since many years has been benefited with huge improvements in its economy and population. A Malaysian state, constituted the highest percentage of waste nearing $46 \%$, which in turn consisted of paper and plastic constituents 15 and $14 \%$ respectively, Fauziah et al [13].

\section{General Aspects}

For a university to develop its very own EMS, and getting, a highlight was thrown on practices already in place with those of future needs to adopt the systems. It was determined that the universities tried to improve their existing practices for new systems development. The environment department, as a condition of ISO needed manuals to be maintained for solid, liquid, air, chemical and other hazardous wastes. The entire system needed more rigorous record keeping and documentation, which in turn led the mangers of multifarious departments to conduct environmental assessments, calibrate laboratory equipment's in order to make the system more standardized. In Pakistani Universities, It was emphasized that the rate of environmental issues awareness is very low but people are trying to learn more about it. United Kingdom has introduced a bus powered entirely by human and food waste. The bus with a seating capacity of 40 people is named Bio -bus. The bus may provide a sustainable way of fueling public transport reducing on pollution in cities. In Pakistan such aspects could also be given priority as a public service to eradicate pollution hazards and lower down fuel costs especially in higher education institutions.

\section{EMS 14001: 2008 Requisites}

According to McDonald et al., [7] the EMS ISO 14001 standard is comprised of various mandatory clauses, the most relevant are "planning, policy, operations and continual improvement." Whitelaw [14] emphasized that the demand for an EMS was long awaited, and attempted many times for the engineering of an individual standard to cater the activities of an organization /university in its entirety and to be used as a future model.

McDonald et al [7] further emphasized that the organizations are inspired for successful inter gradations of their management systems. For successful adoption of ISO 14001:2004 EMS the sub factors like Technology Assessment (TA) are as also being implemented by taking initiatives of the following immediate requirements given in Table-2;

\begin{tabular}{|c|c|}
\hline Requirements & Needs and implementation portfolios \\
\hline Systematic Approach & $\begin{array}{c}\text { Documentation of EMS in accordance with } \\
\text { standard }\end{array}$ \\
\hline Policy Guidelines & $\begin{array}{c}\text { Establish the universities own environmental } \\
\text { policy }\end{array}$ \\
\hline $\begin{array}{c}\text { Planning } \\
\text { \&Development }\end{array}$ & Establish objectives and programs \\
\hline Operational Aspects & Establish an emergency management system \\
\hline Regular Surveillance & Conduct internal audits in universities regularly \\
\hline Reviews & Perform environmental management reviews \\
\hline
\end{tabular}

Robert and Thomas [15] mentioned that the refuse-derived fuels could be utilized by reprocessing .continuous efforts are made for the establishment of EMS systems. Zuckerman [16] stated that needs of market give rise to development of standards. The function of ISO is to identify the interests of all stakeholders thereby constituting international standards based on a unanimous agreement of member nations.

\section{Status of Adoption of EMS 14001}

The following Pakistani Universities / Organizations being adopted EMS ISO 14001 and moving towards Internationalization on faster track as mentioned in following Table-3; 


\begin{tabular}{|c|c|c|}
\hline & Name of Pakistani University / Organization & $\begin{array}{c}\text { Adoption of } \\
\text { EMS }\end{array}$ \\
\hline 1 & $\begin{array}{c}\text { COMSATS Institute of Information Technology } \\
\text { (CIIT) }\end{array}$ & Progressing \\
\hline 2 & University of Karachi & Progressing \\
\hline 3 & PIQC Institute of Quality, Lahore & Progressing \\
\hline 4 & International Islamic University Islamabad & Progressing \\
\hline 5 & $\begin{array}{c}\text { Lahore University of Management Sciences } \\
\text { (LUMS) }\end{array}$ & Adopted \\
\hline 6 & Bahauddin Zakariya University Multan & Progressing \\
\hline 7 & $\begin{array}{c}\text { National Development Complex (NESCOM) } \\
\text { Islamabad }\end{array}$ & Progressing \\
\hline 8 & $\begin{array}{c}\text { University of Engineering and Technology UET } \\
\text { Lahore }\end{array}$ & Progressing \\
\hline 9 & $\begin{array}{c}\text { National University of Science and Technology } \\
\text { (NUST) Islamabad }\end{array}$ & Progressing \\
\hline
\end{tabular}

\section{National Ranking of Universities in Pakistan}

As per Pakistan Higher Education Commission Report [17] the national ranking for the year 2014 of top 10 Pakistani universities that indicated that; Quaid-e-Azam University Islamabad has attained at the top and COMSATS Institute of Information and Technology at the 4th position.

\section{EMS Adoption Trend in CIIT Pakistan}

- Making a policy highlighting commitment to eradicate pollution and emphasis on continuous improvement.

- Aiming at improving the entire performance related to comply with every single statutory and regulatory requirement.

- An effort to minimize the risks of pollution and hazardous wastes.

- Implementing the EMS comprises of: employee training in order to meet targets.

- To carry out audits of EMS and rectifying errors in the system.

- Top management commitments exists to ensure for its continuing performance and declaring CIIT campuses as "Green Future Campuses", more attractive for academic and research pursuits user friendly non-hazardous for health.

- The Level of implementation of EMS (respondent perception) along with assessment of internal and external barriers.

\section{Methodology}

Sequential questionnaire were engineered to meet objectives. These were constituted for the official holdings of position of respondents, stakeholders' categories and a universities financial situation analysis.

\section{Research Hypothesis}

The major hypotheses engineered for this research were: (a) competitive universities already have acquired certifications for international standards pertaining to campus ecology and quality (b) degree of which an international standard is put in place is very remarkable (c) connection between environment, quality and safety is not weak (d) more than the internal factors the external factors are strong for the creation of an EMS. The analysis showed the difference between organizations that have adopted EMS only with those who were having additional standards of quality and safety in addition to 14001 . It was found that a combination of single and additional factors lead to a better and positive organization and environmental profile which supports the hypothesis that external factors are stronger than internal.

\section{Data Analysis}

A survey was conducted and data was analyzed to investigate the availability of websites of universities having an integrated EMS system. About 60 websites of the different universities were visited, 44 universities were sent Proforma on institutional performances related to 14001 . The universities were also visited in person to do file report surveys on ISO 14001. It was found that almost 15 universities were in the process of adopting the EMS systems, while one had already achieved. All the stakeholders held it beneficial and a lot of awareness was found. The data showed that there was a very negligible level of awareness among students, an enhanced awareness level amongst top management and zero awareness level amongst the lower staff. 44 HEC universities were taken as a sample over the period of one year (June, 2014-2015). The efforts towards environmental performance of every single university were studied carefully. The efficacy and usefulness of the universities adopting it were measured against the ones not adopting it .It was analyzed, that the universities which were using it had a better self-image, a greater market value and a far much better performance related to the ones which were not using it. $T$ resulted in reduced environmental pollutants and decreased sewerage leaks .It promoted the generation of Green campuses. Our major effort was thus to test the hypothesis that adopting an EMS system leads to better results and it was proved that it certainly did.

The questionnaires were sent and made follow-up emails to universities for which we did not get any response of. A major portion of the analysis used in this research relies on the Performa and questionnaire are responses which were received by January 2015 . The response data was analyzed to ascertain certain presumptions of adoption EMS in such higher education sector universities.

The communication efforts were multiplied and again imitated to contact through phone calls to the universities and further emphasized on the following points;

- What motivated your university to adopt ISO 14001 ?

- How your campus got involved in these discussions?

- You receive any financial benefits?

- What were the limitations? And problems you encountered

- What were the major strengths of adopting ISO 14001 
All these responses were again analyzed amicably. Overall study endeavored that the adoption of EMS create a positive impact on the university and it will definitely results enhanced performance, which included prevention of pollution $45 \%$, increased awareness $70 \%$, recycling of waste $35 \%$.we grouped the universities in accordance with their size which included number of employees and annual revenue that it generates. Almost all the universities unanimously agreed that adopting such systems does have benefits to attract more international students, joint international research projects and academic excellence and declaring university campuses "environment friendly and green campuses".

\section{Research Problem}

Pakistani universities are facing multifaceted challenges that include inadequate sanitary conditions, financial constraints, non-conducive environmental conditions and lack of awareness related to environmental and health hazards.

\section{Limitations}

The research encountered manifold limitations such as studying EMS of various universities, relevant data collection, laying a comparative analysis with already in place and functioning EMS of universities, communication and information collection from stakeholders, discriminative responses, time constraints and a rigorous effort to adopt such system for CIIT Pakistan.

\section{Conclusions}

If all International universities and particularly Pakistani accredited universities follow ISO 14001 then it has to make sure that this standard addresses continuous improvement by adopting the specified version and clauses of International EMS standard. The aims and goals would have to evaluate improvement compared to those goals. The top officials of the university campuses periodically review the progress and outcomes. It is evident from all relevant views of the researchers quoted as secondary research literature review that EMS-ISO 14001 benefits universities in a way that it controls and brings symmetry in their processes related to environmental management across its campuses in Pakistan and at international level. It requires a documented policy which maintains all training and audit records. It therefore helps conduct such activities in a symmetrical manner. In addition, it keeps the environment friendly by improving campus ecology and declaring as "Green Campuses" and such measures shall lead to attract more international students, diversified cultural mergers and attracting more international funding and joint research and academic projects.

This research attributed that the adoption of EMS-ISO 14001:2008 in Pakistani universities shall take them at par with major top international universities. The knowhow development shall reduce hazardous effects of environment and human life in the declared green campuses of the universities. The main challenges faced by the higher education sector universities in Pakistan is common; lack of awareness and knowledge about EMS systems to the employees and hidden benefits to be untapped consequently at national and international level in the competitive world of knowledge economy. Hoyle (2006) the quality management system standard ISO 9001:2008, constitutes of great management principles which helps top officials giving guidance on continual improvement. Pakistani Universities have shown a gradual change over decades and are trying to create their own EMS systems.

The results indicate that most of the prominent Pakistani universities are on the track for following the Environmental requirements of EMS ISO 14001:2004 and inspired to move towards internationalization. Some of them are on faster track and mostly are not properly familiar to the international standardization benefits. The efficacy level of Lahore University of Management (LUMS) in Pakistan is high that already adopted and successfully practicing required environmental international standards. The other major Pakistani universities are striving to move forward to adopt such international standards, like CIIT Pakistan who have secured 4rth position in top 10 Pakistani universities for the year 2013-14 and is considered on faster track for moving towards internationalization. The leadership commitment in Pakistani universities is most important factor at this transitional stage and relevant legislation at government level is also needed to compete in the international knowledge economic market.

\section{Recommendations}

- An initial gap analysis for emplacement of ISO systems including EMS required to be undertaken in all public and private universities and institutions in the higher education sector of Pakistan.

- The successful role models of international universities may be adopted for competing in the international knowledge economic market.

- In the Pakistani universities, there is a dire need for continuous improvement and adoption of international standardizations as per guidelines of ISO in general and EMS in particular.

- The leadership commitment with a specified policy adoption shall be helpful for declaring educational work places as "Green Campuses" of the universities and institutions in Pakistan.

\section{Recommendations for Future Research}

- A specific primary research is required to assess all public and private sector higher education universities of Pakistan in view of adoption and implementation of 
ISO standards related to quality and environmental management systems, role of government legislations and service providers in the region.

- A comparative study and research to be conducted on ISO standards adaptation by Pakistani universities as compared to other prominent South Asian universities and identifying fast track voyage of Internationalization.

\section{REFERENCES}

[1] Voorhees, J., and Woellner, R. A. International environmental risk management: ISO 14000 and the systems approach. Boka Raton, Fl: Lewis Publishers.(1998)

[2] Von Zharen, W.M. ISO 14001: Positioning your organization". Journal of environmental success. Rockville, MD: ABS Consulting Government Institutes.(2001)

[3] Clements, R.B. Complete Guide to ISO 14000. Prentice Hall, Englewood Cliffs, New Jersey, USA, ISBN-10: 0132429756.(1996)

[4] Block, M. R. Leveraging a quality system to establish an EMS. Quality Progress, (2000) 33(7), 82.

[5] Hartstern, R. F. ISO 14000 environmental management systems and its relationship to ISO 9000. ASQC's Annual Quality Congress Proceedings No 51. (1997)

[6] Jackson, S.L. Integrated management systems for business success. How to integrate ISO 9000 and ISO 14000 systems". Environmental Quality Management, (2001) vol. 8, No. 1, $65-68$

[7] McDonald, M., Mors, T. A., and Phillips, A. Management system integration: Can it be done? Quality Progress, http://asq.org/data/subscriptions/qp/2003/1 003/qp 1003 McDonald ,(2003)

[8] Hoyle, D. Ed. ISO 9000 Quality Systems. Handbook. UK: Butterworth-Heinemann International Organization for Standardization. (2008)

[9] Annual Report COMSATS Institute of Information Technology, Islamabad Pakistan. www.comsats.edu.pk (2012-13)

[10] Schaarsmith, J.H. Implementing the ISO 14001 environmental management system specifications. EMS Guides, Environmental Management System Consortium (EMSC), University of Massachusetts Lowell, (2005) Version 2.0. R1, 9/05

[11] Salim, M.R. Towards sustainable waste management challenges after 50 years independence. University of Technology Malaysia, (2005) No. 29.

[12] Bai, R., and M. Sutanto, The practice and challenges of solid waste management in Singapore. Waste Manage, (2002)22: 557-567.

[13] Fauziah, S.H., Simon. C., and Agamuthu, P. Municipal solid waste management in Malaysia-possibility of improvement. Malaysian Journal of Science, (2004) 23: 61-70.

[14] Whitelaw, K. ISO 14001 Environmental Systems. Handbook (Second Edition). Oxford: Elsevier Butterworth-Heinemann (2004)

[15] Thomas and Robert I.G. Environmental Management Processes and Practices for Australia. Federation Press, Sydney, Australia (2005)

[16] Zuckerman, A. International standards desk reference. New York: amacom (1997)

[17] Ranking, Pakistan Higher Education Institutions HEI's. Higher Education Commission, Islamabad, Pakistan. www.hec.gov.pk (1997) 